\title{
UPAYA MENINGKATKAN KEMAMPUAN BERFIKIR KRITIS BIOLOGI SISWA MELALUI MODEL PEMBELAJARAN KONTEKSTUAL (CONTEXTUAL TEACHING AND LEARNING) DENGAN BERBANTUAN MEDIA PPT DI SMA NEGERI 1 PANYABUNGAN UTARA
}

\author{
Ira Anugrah, Sahlan Tuah, Nurmaini Ginting \\ Pendidikan Biologi, FKIP Universitas Muhammadiyah Tapanuli Selatan \\ sahlan.tuah@um-tapsel.ac.id
}

\begin{abstract}
The problem in this research is the concept of critical biological thinking which became one of the most important things in the learning process that is through the application of Contextual Teaching Learning Model (CTL). The reason for this research is to know the improvement of critical thinking of student biology through the application of Contextual Learning Model an the material. The human Regulation system in class XI IPA $^{1}$ SMA Negeri 1 North Panyabungan academic year 2016-2017. This type of research is Classroom Action Research. Where the subject of study is the students of class XI IPA ${ }^{1}$ SMA Negeri 1 North Panyabungan consisting of 25 students. While techniques and data collected. Based on the result of critical thinking test of the biology of students cycle I am $76 \%$, and cycle II is $84,33 \%$, and the result of the increase of student activity in the cycle is I is $68 \%$ and cyle II $86,40 \%$.
\end{abstract}

Keywords: Critical thinking of student biology, Contextual Learning model (CTL), human regulatory system.

\begin{abstract}
Abstrak
Penelitian ini bertujuan untuk mengetahui peningkatan berfikir kritis biologi siswa melalui penerapan model pembelajaran kontekstual pada materi Sistem Regulasi Manusia di kelas XI IPA ${ }^{1}$ SMA Negeri 1 Panyabungan Utara tahun pelajaran 20162017. Jenis penelitian ini adalah Penelitian Tindakan Kelas (classroom research) dengan dua siklus. Subjek penelitian adalah siswa kelas XI IPA ${ }^{1}$ SMA Negeri 1 Panyabungan Utara yang terdiri dari 25 orang siswa. Teknik dan alat pengumpul data yaitu tes dan observasi. Berdasarkan hasil tes berfikir kritis biologi siswa siklus I sebesar $76 \%$ dan siklus II sebesar $84,33 \%$. Hasil peningkatan aktivitas siswa pada siklus I sebesar $68,00 \%$ dan pada siklus II $86,40 \%$.
\end{abstract}

Kata kunci: Berfikir Kritis, Model Pembelajaran Kontekstual (CTL), Sistem Regulasi Manusia.

107 | PeTeKa (Jurnal Penelitian Tindakan Kelas dan Pengembangan Pembelajaran) 


\section{PENDAHULUAN}

Pembelajaran merupakan proses membelajarkan yang artinya mangacu kesegala daya upaya bagaimana membuat seseorang belajar, bagaimana menghasilkan terjadinya peristiwa belajar di dalam diri orang tersebut. Tugas pembelajaran dilaksanakan oleh guru.

Guru harus mampu mempengaruhi daya atau kemampuan siswa dalam memfokuskan pertanyaan sehingga suasana belajar menjadi aktif dan 'produktif. Selain itu, guru juga harus mampu memotivasi terjadinya kemampuan siswa untuk menganalisis argument terhadap materi yang di ajarkan sehingga terjadinya proses belajar mengajar dua arah yaitu guru dan siswa.

Menurut Iskandar, (2009)

Kemampaun berpikir merupakan kegiatan penalaran yang reflektif, kritis, dan kreatif, yang berorientasi pada suatu proses intelektual yang melibatkan pembentukan konsep (conceptualizing), aplikasi, analisis, menilai informasi yang terkumpul (sintesis) atau dihasilkan melalui pengamatan, pengalaman, refleksi, komunikasi sebagai landasan kepada suatu keyakinan (kepercayaan) dan tindakan.

Fisher (2008) menambahkan, berpikir kritis adalah (1) suatu sikap mau berfikir secara mendalam tentang masalah-masalah dan hal-hal yang berada dalam jamgkauan pengalaman seseorang; (2) pengetahuan tentang metode-metode pemeriksaan dan penalaran yang logis; dan (3) semacam suatu keterampilan untuk menerapkan metode-metode tersebut. Berfikir kritis menuntut upaya keras untuk memeriksa setiap keyakinan atau pengetahuan asumtif berdasarkan bukti pendukungnya dan kesimpulan- kesimpulan lanjutan yang diakibatkannya. Johnson (2002) berpikir kritis merupakan sebuah proses yang terarah dan jelas yang digunakan dalam kegiatan mental seperti memecahkan masalah, mengambil keputusan, membujuk, menganalisis asumsi, dan melakukan penelitian ilmiah.

Nurhadi, (2002) Model Kontekstual (Contextual Teaching and Learning) adalah konsep belajar yang membantu guru mengaitkan antara materi yang diajarkannya dengan situasi dunia nyata siswa dan mendorong siswa membuat hubungan antara pengetahuan yang dimilikinya dengan penerapannya dalam kehidupan mereka sehari-hari. Sanjaya (2010) menjelaskan, pendekatan model pembelajaran Kontekstual memiliki tujuh langkah yang harus diterapkan dalam pembelajarannya yakni: konstruktivisme (Constructivism), menemukan (Inquiry), bertanya (Questioning), masyarakat belajar (Learning Community), pemodelan (Modeling), refleksi (Reflection) dan penilaian sebenarnya (Authentic Assessment).

Sukiman (2012) mengemukakan bahwa dengan Microsoft Office Power Point ini kita dapat merancang dan membuat presentasi yang lebih menarik dan profesional. Suhendi (2009) mengemukakan Microsoft Office Power Point merupakan program aplikasi kantor bertipe slide show (lembar kerja yang merupakan kaca objek yang menampilkan objek bergantian) yang digunakan untuk mempresentasikan konsep dan argument yang ingin ditunjukkan pada orang lain dengan tampilan grafis yang menarik. 
Ira Anugrah, dkk. Upaya Meningkatkan Kemampuan Berfikir Kritis...

\section{METODE}

Adapun jenis penelitian ini adalah penelitian tindakan kelas (classroom action research), sedangkan model pembelajaran yang akan diterapkan adalah pembelajaran model Kontekstual (Contextual Teaching and Learning) untuk meningkatkan berfikir kritis biologi siswa pada pokok bahasan sistem regulasi manusia.

Teknik pengumpulan data dalam penelitian ini adalah tes dan observasi.

a. Tes

Tes digunakan untuk mendapatkan data tentang berfikir kritis siswa dengan cara melakukan tes pada siswa yaitu berupa soal-soal yang disusun.

b. Observasi aktivitas siswa

Observasi digunakan untuk mengetahui sejauh mana peningkatan interaksi belajar biologi siswa pada saat proses pembelajaran berlangsung pada materi sistem regulasi manusia.

c. Observasi aktivitas guru

Observasi digunakan untuk mengetahui cara guru dalam mengelola pembelajaran pada saat proses pembelajaran berlangsung pada materi sistem regulasi manusia.

Untuk memperoleh data yang diperlukan dalam penelitian ini maka peneliti menggunakan instrumen peneliti berupa lembar tes dan lembar observasi.

a. Lembar Test

Tes berupa Essay tes yang disusun berdasarkan standar isi sebanyak 30 butir untuk siklus I dan siklus II .

b. Lembar Observasi Aktivitas Siswa

Lembar observasi aktivitas siswa ini merupakan lembar untuk mengamati aktivitas selama pembelajaran berlangsung yaitu dengan menggunakan model pembelajaran Kontekstual.

c. Lembar Observasi Aktivitas Guru

Lembar observasi aktivitas guru ini merupakan lembar untuk mengamati aktivitas guru dalam mengelola pembelajaran selama pembelajaran berlangsung yaitu dengan menggunakan model pembelajaran Kontekstul.

\section{HASIL DAN PEMBAHASAN}

Hasil penelitian diuraikan dalam tahapan yang berupa siklus-siklus pembelajaran yang dilakukan dalam proses belajar di kelas yang dilaksanakan di kelas XI IPA ${ }^{1}$ SMA Negeri 1 Panyabungan Utara pada materi Sistem Regulasi Manusia. Adapun tahapan atau siklus yang dilaksanakan yaitu perencaan tindakan, pelaksaan tindakan, observasi dan refleksi.

\section{Hasil Penelitian Tindakan Kelas Siklus I}

Siklus I merupakan pembelajaran dengan pokok bahasan Sistem Regulasi Manusia dengan model Kontekstual (Contextual Teaching and Learning) dilaksanakan kepada siswa untuk meningkatkan berfikir kritis biologi siswadi SMA Negeri 1 Panyabungan Utara. Pembelajaran siklus I berlangsung sebanyak 2 kali pertemuan. Di akhir pertemuan kedua diberikan tes untuk melihat berfikir kritis biologi siswa.

Dari hasil tes berfikir kritis biologi siswa Siklus I terdapat pada tabel 1: diperoleh nilai rata-rata 7,48 dengan kategori "Cukup" soal indikator nomor satu (memfokuskan pertanyaan), rata-rata 7,78 dengan kategori "Baik" pada indikator soal nomor dua (menganalisis argument), rata-rata 7,84 dengan kategori "Baik pada soal indikator nomor tiga (bertanya dan 
menjawab pertanyaan), rata-rata 7,00 dengan kategori "Cukup" pada indikator nomor empat (mendeduksi dan mempertimbangkan hasil deduksi), rata-rata 7,12 dengan kategori "Cukup" pada soal indikator nomor lima (menginduksi dan mempertimbangkan hasil induksi), rata-rata 7,12 dengan kategori "Cukup" menjawab soal indakator nomor enam (mendefinisikan istilah dan mempertimbangkan suatu definisi), rata-rata 7,20 dengan kategori "Cukup" mampu menjawab soal indikator nomor tujuh (mengidentifikasi asumsi-asumsi) dan nilai rata-rata 7,64 dengan kategori "Baik" menjawab soal indikator nomor delapan (menentukan suatu tindakan)

Tabel1: Rekapitulasi Hasil Tes Berfikir Kritis Siklus I

\begin{tabular}{ccc}
\hline Indikator & Hasil & Keterangan \\
\hline 1 & 7.48 & Cukup \\
2 & 7.78 & Baik \\
3 & 7.84 & Baik \\
4 & 7.00 & Cukup \\
5 & 7.12 & Cukup \\
6 & 7.84 & Baik \\
7 & 7.20 & Cukup \\
8 & 7.64 & Baik \\
\hline Jumlah & 59.9 & \\
Rata-rata & 7.4 & Cukup \\
\hline
\end{tabular}

Rata-rata keseluruhan yang diperoleh siswa pada Siklus I 7,4 dengan kategori "Cukup" dan persentase ketuntasan masih $76 \%$. Hasil yang diperoleh siswa pada siklus I ini belum mencapai indikator yang telah ditetapkan dengan kategori "Baik", sementara kriteria yang ditetapkan adalah terdapat minimal $80 \%$ siswa harus memiliki hasil tingkat berfikir kritis pada kategori "Baik". Melihat dari hal tersebut berarti tingkat berfikir kritis biologi siswa belum tercapai sesuai dengan kriteria yang diharapkan yakni mencapai $80 \%$ maka penelitian ini akandilanjutkan pada siklus II.

Dari data dapat diklasifikasikan nilai berfikir kritis siswa sebagai berikut:

(a) Menentukan rentang $=$ Data besar data terkecil

$$
\text { Rentang }=84-51
$$$$
=33
$$

(b)Banyak kelas interval $=1+3,3(\log 25)$

$$
=6
$$

(c)Panjang kelas
1) $P=\frac{33}{6}$
2) $P=5.5$
3) $P=5$

Tabel2: Distribusi Frekuensi Tes Berfikir Kritis Siklus I

\begin{tabular}{cccccc}
\hline NO & Interval & F & D & Fd & Fd $^{2}$ \\
\hline 1 & $81-85$ & 4 & +1 & 4 & 4 \\
2 & $76-80$ & 14 & 0 & 0 & 0 \\
3 & $71-75$ & 2 & -1 & -2 & 2 \\
4 & $66-70$ & 0 & -2 & 0 & 0 \\
5 & $61-65$ & 4 & -3 & -12 & 36 \\
6 & $56-60$ & 0 & -4 & 0 & 0 \\
7 & $51-55$ & 1 & -5 & -5 & 25 \\
\hline \multicolumn{2}{c}{ Jumlah } & 25 & -14 & -15 & 67 \\
\hline
\end{tabular}

\section{Hasil Observasi Aktivitas Siswa Siklus I}

Pengamatan atau observasi merupakan bagian proses dari pengumpulan data yang diperlukan dalam penelitian. Guru yang bertindak sebagai kolabolator mengamati guru yang bertindak sebagai guru PTK yang sedang mengajar di kelas dengan pokok bahasan sistem regulasi manusia. Pelaksanaan dilakukan pada saat guru melaksanakan proses pembelajaran dengan model pembelajaran Kontekstual (Contextual Teaching and Learning) untuk meningkatkan berfikir kritis biologi siswa. Observer memiliki peran mengamati dan mendokumentasikan semua aktivitas 
Ira Anugrah, dkk. Upaya Meningkatkan Kemampuan Berfikir Kritis...

siswa yang terjadi dikelas ketika tindakan dilakukan.

Hasil pengamatan terhadap aktivitas siswa dalam pembelajaran setiap pertemuan sebanyak 2 kali pertemuan tatap muka dinyatakan dengan persentase, dan hasil tersebut disajikan secara ringkas pada tabel 4: dapat dijelaskan setiap indikator aktivitas siswa bahwa: aktivitas siswa pada indikator "Berpikir Kompleks" dengan rata-rata 0,64 berada pada kategori "Cukup Baik", indikator aktivitas siswa "Memproses Informasi" dengan rata-rata sebesar 0,60 berada

Dari tabel aktivitas siswa siklus I, dapat dijelaskan bahwa kadar aktivitas siswa yang terdiri dari beberapa indikator, seperti: "Berpikir Kompleks", "Memproses Informasi", "berkomunikasi Efektif", "Bekerja Sama atau Berkolaborasi”, dan Berdaya Nalar yang Efektif" rata-rata sebesar 0,68 atau $80 \%$. Sedangkan kadar aktivitas siswa yang direncanakan dalam penelitian ini adalah $\geq 80 \%$.

Berdasarkan uraian, dapat diperoleh bahwa kadar aktivitas siswa ternyata belum terpenuhi sesuai dengan kriteria yang diharapkan. Dengan demikian ditinjau dari segi kadar aktivitas aktif siswa setelah merujuk keefektifan aktivitas seperti yang direncanakan dalam penelitian ini maka disimpulkan bahwa penelitian ini akan dilanjutkan pada siklus II.

\section{Hasil Penelitian Tindakan Kelas Siklus II}

pada kategori "Cukup Baik", indikator aktivitas siswa "Berkomunikasi Efektif" dengan rata-rata 0,72 berada pada kategori "Baik", indikator aktivitas siswa "Bekerja sama atau berkolaborasi" dengan rata-rata 0,68 berada pada kategori "Cukup Baik:", dan indikator aktivitas siswa "Berdaya Nalar yang Efektif" dengan rata-rata 0,76 berada pada kategori "Baik". Hal ini menunjukkan siswa belum berantusias dalam mengikuti pembelajaran dengan model pembelajaran yang diterapkan sehingga kategori yang diperoleh masih kurang. Perencanaan pada siklus II merupakan tindak lanjut refleksi pada siklus I, dengan revisi/ perbaikan di beberapa aspek seperti instrumen yang digunakan dan perangkat pembelajaran seperti RPP dan LKS. Adapun perubahan/ perbaikan yang dilakukan adalah sebagai berikut :

Revisi perangkat pembelajaran yang disusun di atas untuk pertemuan berikutnya pada siklus II untuk meningkatkan berfikir kritis siswa dalam pembelajaran biologi. Tes yang disusun adalah tes berfikir kritis biologi siswa yang terdiri dari 10 butir soal yang masing - masing pernyataan disusun berdasarkan indikator berfikir kritis. Tindakan pada siklus II ini merupakan tindak lanjut hasil refleksi siklus I. Di akhir pembelajaran siklus II berlangsung, pada pertemuan kedua dilaksanakan pembagian tes berfikir kritis biologi siswa.

Tabel 3: Kadar Aktivitas Siswa Siklus I

\begin{tabular}{|c|l|c|c|c|}
\hline No & \multicolumn{1}{|c|}{ Indikator } & Hasil & Persentase & Kategori \\
\hline 1 & Berpikir Kompleks & $\mathbf{0 , 6 4}$ & $64 \%$ & Cukup Baik \\
\hline 2 & Memproses Komunikasi & $\mathbf{0 , 6 0}$ & $60 \%$ & Cukup Baik \\
\hline 3 & Berkomunikasi Efektif & $\mathbf{0 , 7 2}$ & $72 \%$ & Baik \\
\hline 4 & Bekerjasama ata Berkolaborasi & $\mathbf{0 , 6 8}$ & $68 \%$ & Cukup Baik \\
\hline 5 & Berdaya nalar yang efektif & $\mathbf{0 , 7 6}$ & $76 \%$ & Baik \\
\hline \multicolumn{2}{|l|}{ Rata - rata persentase indikator } & $\mathbf{0 , 6 8}$ & $\mathbf{6 8 \%}$ & Cukup Baik \\
\hline
\end{tabular}


Tabel4: Revisi Angket dan Perangkat Pembelajaran Berdasarkan Hasil Refleksi Siklus I

\begin{tabular}{|c|c|c|c|}
\hline Yang direvisi & Sebelum direvisi & Sesudah direvisi & $\begin{array}{c}\text { Alasan } \\
\text { merevisi }\end{array}$ \\
\hline $\begin{array}{l}\text { Cara belajar } \\
\text { siswa agar lebih } \\
\text { meningkatkan } \\
\text { berfikir kritis } \\
\text { biologi siswa }\end{array}$ & $\begin{array}{l}\text { Siswa kurang aktif } \\
\text { dalam kegiatan } \\
\text { pembelajaran }\end{array}$ & $\begin{array}{l}\text { Aktivitas belajar } \\
\text { siswa telah } \\
\text { meningkat sesuai } \\
\text { dengan kriteria } \\
\text { minimal } 80 \%\end{array}$ & $\begin{array}{l}\text { Siswa } \\
\text { kesulitan } \\
\text { dalam } \\
\text { menyelesai } \\
\text { kan soal }\end{array}$ \\
\hline & & & $\begin{array}{l}\text { Siswa } \\
\text { kurang } \\
\text { aktif } \\
\text { karena } \\
\text { kurang } \\
\text { mengerti } \\
\text { dengan } \\
\text { materi } \\
\text { yang } \\
\text { diajarkan. }\end{array}$ \\
\hline
\end{tabular}

Berdasarkan hasil tes berfikir kritis biologi siswa pada siklus II dapat diklasifikasikan tabel 5:

Tabel5: Rekapitulasi Hasil Tes Berfikir Kritis Siklus II

\begin{tabular}{|c|c|c|}
\hline Indikator & Hasil & Keterangan \\
\hline $\mathbf{1}$ & 7.32 & Cukup \\
\hline $\mathbf{2}$ & 8.28 & Baik \\
\hline $\mathbf{3}$ & 8.64 & Sangat Baik \\
\hline $\mathbf{4}$ & 8.16 & Baik \\
\hline $\mathbf{5}$ & 6.32 & Cukup \\
\hline $\mathbf{6}$ & 8.40 & Sangat Baik \\
\hline $\mathbf{7}$ & 9.32 & Sangat Baik \\
\hline $\mathbf{8}$ & 8.04 & Baik \\
\hline Jumlah & $\mathbf{6 4 . 4 8}$ & \\
\hline Rata-rata & $\mathbf{8 . 0 6}$ & Baik \\
\hline
\end{tabular}

Dari hasil tes siswa siklus II di atas, diperoleh nilai rata-rata 7,32 dengan kategori "Cukup" soal indikator nomor satu (memfokuskan pertanyaan), rata-rata 8,28 dengan kategori "Baik" pada indikator soal nomor dua (menganalisis argument), rata-rata 8,64 dengan kategori "Sangat Baik pada soal indikator nomor tiga (bertanya dan menjawab pertanyaan), rata-rata 8,16 dengan kategori "Baik" pada indikator nomor empat (mendeduksi dan mempertimbangkan hasil deduksi), ratarata 6,32 dengan kategori "Cukup" pada soal indikator nomor lima (menginduksi dan mempertimbangkan hasil induksi), rata-rata 8,40 dengan kategori "Sangat Baik" menjawab soal indakator nomor enam (mendefinisikan istilah dan mempertimbangkan suatu definisi), rata-rata 9,32 dengan kategori "Sangat Baik" mampu menjawab soal indikator nomor tujuh (mengidentifikasi asumsiasumsi) dan nilai rata-rata 8,04 dengan kategori "Baik" menjawab soal indikator nomor delapan (menentukan suatu tindakan). Rata-rata keseluruhan yang diperoleh siswa pada Siklus II 8,06 dengan kategori "Baik" dan persentase ketuntasan $84 \%$. 
Ira Anugrah, dkk. Upaya Meningkatkan Kemampuan Berfikir Kritis...

Berdasarkan hasil yang diperoleh dapat diketahui bahwa tingkat berfikir kritis biologi siswa sudah mengalami peningkatan yaitu berada pada kategori "Baik". Melihat dari hal tersebut berarti tingkat berfikir krtis biologi siswa telah tercapai sesuai dengan kriteria yang diharapkan yakni mencapai lebih dari $80 \%$ maka penelitian ini dapat dihentikan.

Dari data di atas dapat diklasifikasikan nilai berfikir kritis siswa:

Tabel6: Distribusi Frekuensi Tes Berfikir Kritis Siklus II (a) Menentukan rentang = Data besar - data terkecil

Rentang $=87-60$

$$
=27
$$

(b)Banyak kelas interval $=1+3,3(\log 25)$

$$
=6
$$

(c)Panjang kelas

$$
\begin{aligned}
& \mathrm{P}=\frac{27}{6} \\
& \mathrm{P}=4.5 \\
& \mathrm{P}=4
\end{aligned}
$$

\begin{tabular}{cccccc}
\hline NO & Interval & F & D & Fd & Fd $^{2}$ \\
\hline 1 & $84-87$ & 11 & 0 & 0 & 0 \\
2 & $80-83$ & 8 & -1 & -8 & 64 \\
3 & $76-79$ & 2 & -2 & -4 & 16 \\
4 & $72-75$ & 0 & -3 & 0 & 0 \\
5 & $68-71$ & 1 & -4 & -4 & 16 \\
6 & $64-67$ & 1 & -5 & -5 & 25 \\
7 & $60-63$ & 2 & -6 & -12 & 144 \\
\hline \multicolumn{7}{c}{ Jumlah } & 25 & -21 & -33 & 265 \\
\hline
\end{tabular}

Hasil Observasi Aktivitas Siswa Siklus II

Hasil pengamatan terhadap aktivitas

\begin{tabular}{|c|c|c|c|c|}
\hline No & Indikator & Hasil & $\begin{array}{c}\text { Persen- } \\
\text { tase }\end{array}$ & Kategori \\
\hline 1 & $\begin{array}{l}\text { Berpikir } \\
\text { Kompleks }\end{array}$ & 0,84 & $84 \%$ & Baik \\
\hline 2 & $\begin{array}{l}\text { Memproses } \\
\text { Komunikasi }\end{array}$ & 0,88 & $88 \%$ & $\begin{array}{c}\text { Sangat } \\
\text { Baik }\end{array}$ \\
\hline 3 & $\begin{array}{l}\text { Berkomunikasi } \\
\text { Efektif }\end{array}$ & 0,88 & $88 \%$ & $\begin{array}{c}\text { Sangat } \\
\text { Baik }\end{array}$ \\
\hline 4 & $\begin{array}{l}\text { Bekerjasama } \\
\text { Berkolaborasi }\end{array}$ & 0.88 & $88 \%$ & Baik \\
\hline 5 & $\begin{array}{l}\text { Berdaya nalar } \\
\text { yang efektif }\end{array}$ & 0.88 & $88 \%$ & $\begin{array}{c}\text { Sangat } \\
\text { Baik }\end{array}$ \\
\hline & $\begin{array}{l}\text { Rata - rata } \\
\text { persentase } \\
\text { indikator }\end{array}$ & 4,36 & $86,40 \%$ & $\begin{array}{c}\text { Sangat } \\
\text { Baik }\end{array}$ \\
\hline
\end{tabular}
siswa dalam pembelajaran selama 2 kali pertemuan pada siklus II ini dapat dilihat pada tabel 8:

Tabel 8: Kadar Aktivitas Siswa Siklus II
Dari tabel aktivitas siswa siklus II dapat dijelaskan setiap kategori pengamatan sebagai berikut : Kadar aktivitas siswa pada aspek (1) Berpikir Kompleks diperoleh rata-rata 0,84 , aspek (2) Memproses Informasi diperoleh rata-rata 0,88 , aspek (3) Berkomunikasi efektif diperoleh ratarata 0,88, aspek (4) Bekerjasama atau berkolaborasi diperoleh rata-rata 0,88 , dan aspek (5) Berdaya nalar yang efektif diperoleh rata-rata 0,88 . Ini menunjukkan kalau hampir seluruh siswa sudah aktif dalam mengikuti mampu menyelesaikan tugas dan mampu merangkum pelajaran yang telah dipelajari.

Dari hasil tersebut dapat disimpulkan bahwa siswa sudah bisa menggunakan model pembelajaran Kontekstual (Contextual Teaching and Learning) dan dapat kita lihat sebagian 
dari aspek penilaian telah mengalami peningkatan dari siklus sebelumnya.

Dari tabel aktivitas siswa siklus II di atas terlihat jelas peningkatan kadar aktivitas siswa dari siklus I sebelumnya, Secara keseluruhan diperoleh nilai rata - rata aktivitas siswa sebesar 4,36 dengan persentase $86,40 \%$

Hasil di atas menunujukkan bahwa kadar aktivitas siswa dalam proses pembelajaran dengan model pembelajaran Kontekstual (Contextual Teaching and Learning) pada siklus II sudah berada pada kategori Sangat Baik dan sudah sesuai dengan kadar yang diharapkan dalam penelitian ini yaitu $86,40 \% \quad(\geq 80 \%)$. Hal tersebut menunjukkan kalau siswa sudah terbiasa dengan model pembelajaran Kontekstual (Contextual Teaching and Learning). Sehingga dapat disimpulkan penelitian ini berhenti pada siklus II.

\section{SIMPULAN}

Berdasarkan uraian dari pembahasan dapat diambil beberapa kesimpulan sebagai berikut : Hasil tes berfikir kritis biologi siswa setelah dilakukan penerapan Model Pembelajaran Kontekstual (Contextual Teaching and Learning) mengalami peningkatan, yang memiliki berfikir kritis biologi siswa pada siklus I diperoleh 19 siswa $(76,00 \%)$ yang memiliki berfikir kritis biologi siswa pada siklus II diperoleh 21 siswa $(84,00 \%)$.

Model Pembelajaran

Kontekstual (Contextual Teaching and Learning) dapat meningkatkan aktivitas siswa yang dilihat dari hasil observasi aktivitas siswa siklus I sebesar $68 \%$ ,hasil observasi siswa siklus II sebesar $86,40 \%$ dan hasil yang diperoleh telah terpenuhi.

\section{DAFTAR PUSTAKA}

Fisher, alex. 2008. Berfikir Kritis: Sebuah Pengantar. Jakarta: Erlangga.

Iskandar, Agung. 2009. Meningkatkan Kreativitas Pembelajaran Bagi Guru. Jakarta: Bestari Buana Murni.

Johnson Elaine B. 2002. Contextual Teaching \& Learning Menjadikan Kegiatan BelajarMengajar Mengasyikkan dan Bermakna. Bandung: MLC.

Kusumah, Wijaya dan Dedi Dwitagama. 2011. Mengenal

Penelitian Tindakan Kelas. Edisi : 2. Jakarta : PT Indeks.

Nurhadi. 2002. Pendekatan kontekstual, Jakarta : Departemen Pendidikan Nasional, Dirjendikdasmen.

Sanjaya, Wina. 2010. Strategi Pembelajaran Berorientasi Standar Proses Pendidikan. Jakarta : Prenada Media Group.

Suhendi, Edi.2009. Membuat Desain

Profesional Dengan Adobe

Illustrator. Bandung: Informatika.

Sukiman. 2012. Pengembangan Media Pembelajaran. Yogyakarta: Pedagogia. 